\title{
INEQUALITIES FOR POSITIVE LINEAR MAPS ON HERMITIAN MATRICES
}

\author{
J. MićIĆ, J. PeČArić, Y. SEO AND M. TOMINAGA
}

Abstract. The aim of this work is to generalize the main inequalities in [9] as follows: Let $A$ be a Hermitian matrix, let $\Phi$ be a normalized positive linear map, let $f$ and $g$ be real valued continuous functions and let $F(u, v)$ be a real valued function matrix non-decreasing in its first variable. Real constants $\alpha$ and $\beta$ such that

$$
\alpha I \leqslant F[\Phi(f(A)), g(\Phi(A))] \leqslant \beta I
$$

are determined. If $f$ is a concave (resp. convex) function then the determination of $\beta$ (resp. $\alpha$ ) is reduced to solving a single variable maximization (resp. minimization) problem. Some applications of these results to the power function, the means and the Hadamard product are also given.

Mathematics subject classification (1991): 47A30, 47A63.

Key words and phrases: Inequality, normalized positive linear map, Hermitian matrix, convexity, Hadamard product, mean.

\section{REFERENCES}

[1] T. Ando, Concavity of certain maps of positive definite matrices and applications to Hadamard product, Linear Algebra Appl., 26 (1979), 203-241.

[2] J. Bendat and S. Sherman, Monotone and convex operator functions, Trans. Amer. Math. Soc., 79 (1955), 58-71.

[3] M. D. Choi, A Schwarz inequality for positive linear maps on $C^{*}$-algebras, Illinois J. Math. 18 (1974), 565-574.

[4] C. Davis, A Schwarz inequality for convex operator functions, Proc. Amer. Math. Soc., 8 (1957), $42-44$.

[5] C. Davis, Operator-valued entropy of quantum mechanical measurement, Proc. Japan Acad., 37 (1961), 533-538.

[6] C. Davis, Notions generalizing convexity for functions defined on spaces of matrices, Proc. Symp. Pure Math., 7 (1963), 187-201.

[7] T.Furuta, Extensions of Hölder-McCarthy and Kantorovich inequalities and their applications, Proc. Japan Acad., 2(1997), 38-41.

[8] T.Furuta, Operator inequalities associated with Hölder-McCarthy and Kantorovich inequalities, J. Inequal. Appl., 2(1998), 137-148.

[9] C.-K. Li and R. Mathias, Matrix inequalities involving a positive linear map, Linear and Multilinear Algebra, 41 (1996), 221-231.

[10] A. W. Marshall, I. Olkin, Inequalities: Theory of majorization and its applications, Academic press, 1979.

[11] B. Mond, J. E. Pečarić, Converses of Jensen's inequality for linear maps of operators, Analele Universit. din Timişoara, Seria Math.-Inform., XXXI (1993), 2, 223-228.

[12] B. Mond and J. E. Pečarić, Converses of Jensen's inequality for several operators, Revue d'analyse numer. et de théorie de l'approxim. 23 (1994), 2, 179-183.

[13] B. Mond and J. E. Pečarić, Bounds for Jensen's inequality for several operators, Houston Journal of Mathematics 20 (1994), 4, 645-651. 
[14] B. Mond and J. E. Pečarić, Difference and ratio operator inequalities in Hilbert space, Houston Journal Mathem. 21 (1994), 1, 103-108.

[15] B. Mond and J. E. Pečarić, Matrix convex functions of several variables, Soochow Journal of mathematics 24 (1998), 4, 239-254.

[16] B. Mond, J. E. Pečarić, A matrix version of the Ky Fan generalization of the Kantorovich inequality, Linear and Multilinear Algebra 36 (1994), 217-221.

[17] B. Mond, J. E. Pečarić, A matrix version of the Ky Fan generalization of the Kantorovich inequality II, Linear and Multilinear Algebra 38 (1995), 309-313.

[18] B. Mond and J. E. Pečarić, Matrix inequalities for convex functions, J. Math. Anal. Appl. 209 (1997), $145-153$.

[19] J. Mićić, Y. Seo, S.-E. Takahasi and M. Tominaga, Inequalities of Furuta andMond-Pečarić, Mathematical Inequalities \& Applications, 2 (1999), 83-112.

[20] Y. Seo, S.-E. Takahasi, J. E. Pečarić and J. Mićić, Inequalities of Furuta and Mond-Pečarić on the Hadamard product, J. Inequal. Appl. 5 (2000), 263-285.

[21] G. Visick, An algebraic relationship between the Hadamard and Kronecker product with some applications, Bull. Soc. Math. Belg., 42(1990),275-283. 